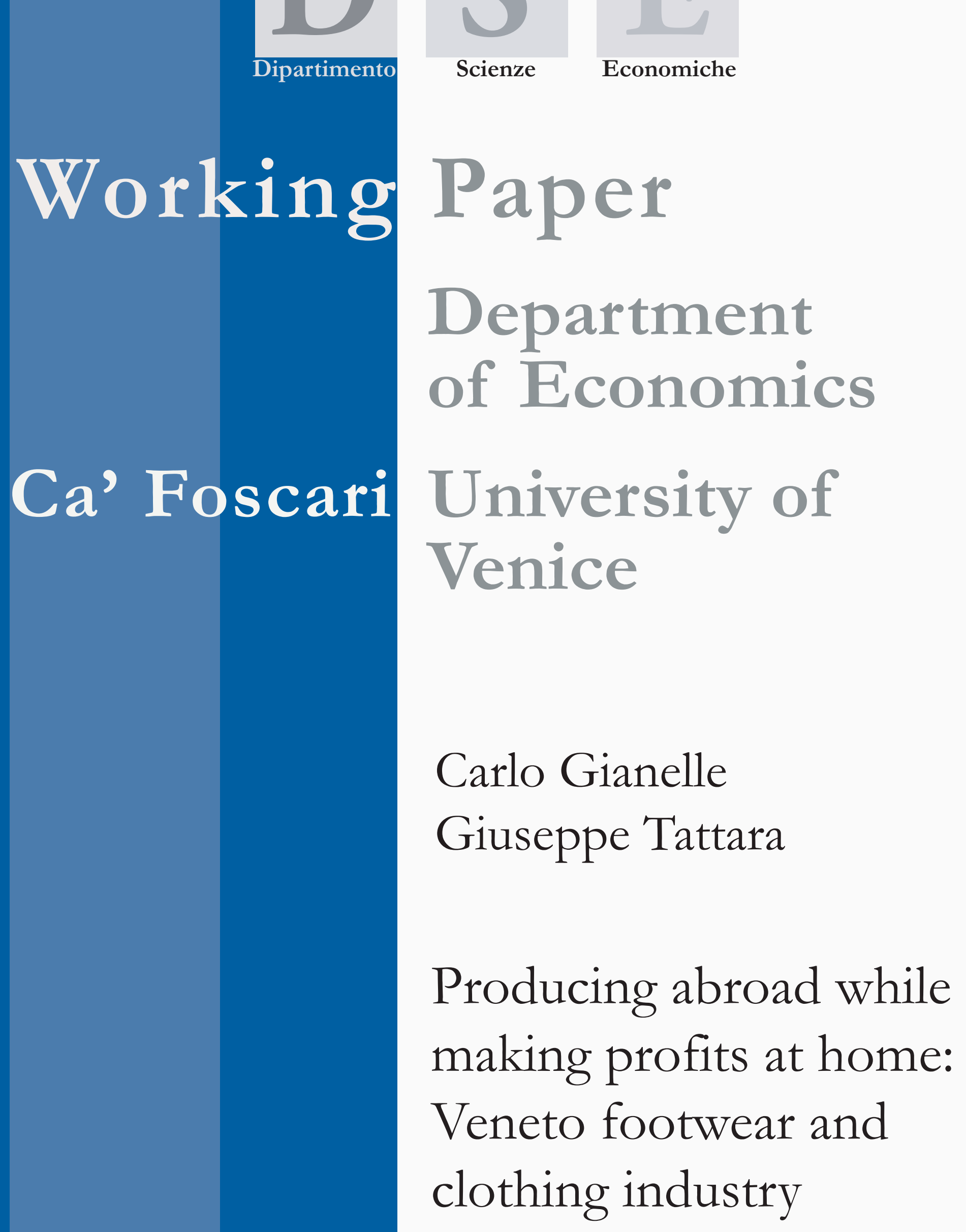




\title{
Producing abroad while making profits at home: Veneto footwear and clothing industry
}

\author{
Carlo Gianelle \\ Giuseppe Tattara \\ Università degli studi di Siena \\ Università degli studi Cà Foschi di Venezia
}

Abstract

First Draft: 15.11.2007

Over the last twenty years globalisation has brought about a sharp increase in the real and financial integration of the worldwide economy. In this closely knit context, the outsourcing of some of the productive and trade activities abroad has become one of the focal points of the policies followed by businesses in order to handle competition at worldwide level. In the 80s Italian clothing and footwear firms faced the increased competition in the international markets by outsourcing to domestic subcontractors and in the 90s transferred much of the previous outsourcing abroad, in countries with low labour costs, mainly in Eastern Europe, North Africa and East Asia.

This paper is aimed to assess the impact of the offshoring strategy on firms. performance. It is based on a survey delivered to a group of 70 final producers, operating in the Veneto, that during the 90s began to manage production on a global scale. Direct investments, subcontracting and partnerships that materialize in product manufacturing abroad are considered as forms of international outsourcing. On this basis, by combining direct observations with balance sheets data, and data on employment stock at the firm's level, the impact of the offshoring decision is evaluated.

The study shows the importance of production management along the global value chain in giving new competitivity to the Veneto traditional sector.

\section{Keywords}

production organization, global value chains, fragmentation, internationalization, clothing industry, Italy.

\section{JEL Codes}

F23, L23, L67

\author{
Address for correspondence: \\ Giuseppe Tattara \\ Department of Economics \\ Ca’ Foscari University of Venice \\ Cannaregio 873, Fondamenta S.Giobbe \\ 30121 Venezia - Italy \\ Phone: (++39) 0412349148 \\ Fax: (++39) $041234917 \overline{76}$ \\ e-mail: tattara@unive.it
}

This Working Paper is published under the auspices of the Department of Economics of the Ca' Foscari University of Venice. Opinions expressed herein are those of the authors and not those of the Department. The Working Paper series is designed to divulge preliminary or incomplete work, circulated to favour discussion and comments. Citation of this paper should consider its provisional character.

\begin{tabular}{|c|c|}
\hline $\begin{array}{r}\text { The Working Paper Series } \\
\text { is availble only on line } \\
\text { (www.dse.unive.it/pubblicazioni) } \\
\text { For editorial correspondence, please contact: } \\
\text { wp.dse@unive.it }\end{array}$ & $\begin{array}{l}\text { Department of Economics } \\
\text { Ca' Foscari University of Venice } \\
\text { Cannaregio 873, Fondamenta San Giobbe } \\
30121 \text { Venice Italy } \\
\text { Fax: ++39 } 0412349210\end{array}$ \\
\hline
\end{tabular}




\section{Introduction ${ }^{1}$}

Globalization has brought about a sharp increase in the real and financial integration of the worldwide economy. In this closely knit context the outsourcing of some of the productive and trade activities abroad becomes the focal point of the policies followed by firms in order to face competition on international markets.

The shift of manufacturers towards countries with lower labour costs was underlined by some experts at the beginning of the 70s and especially involved countries with relatively high labour costs such as USA, Germany, Sweden, Denmark, U.K. (Adam, 1971; Finger 1976; 1977).

Over the last decades the capacity of manufacturing firms to slice the production cycle without incurring high diseconomies has given large impetus to production globalisation and has driven firms in countries, like Italy, with salaries lower than those in the USA and Northern Europe, to look for lower production costs abroad. Additionally the participation of Eastern European countries, Russia, and China to the international consumption market has provided a further incentive to transfer the manufacturing processes abroad by locating outposts in areas close to markets with high sales potential.

To 'measure' the degree of internationalization of a firm is not an easy task: the usual measure is the value of the direct overseas investments made to set up a new company abroad or to purchase one already in existence. Italian overseas investments are modest, and Italian businesses seem to be lagging behind compared to other industrialised countries of a similar size and comparable degree of development. Some scholars who have acquired information from the study of inter-industrial trade flow (Schiattarella, 1999; Kaminski and Ng, 2001; Corò and Volpe, 2003) and from studies on individual companies have reached the conclusion that the process of internationalisation is much wider and detailed than what appears from the data regarding direct investments. A conspicuous part of firms' overseas activities is in fact based on intermediary procedures i.e. trade agreements and subcontracting, particularly important in the case of Italian SMEs (Bigarelli and Ginzburg, 2005). These forms of 'light' integration involve reduced capital flows and temporary commodity flows, as commodities are sent abroad in order to be processed and are subsequently reimported. But intermediate commodity flows blend with the 'normal' transit of goods at Customs, they are not separately recorded, therefore they are difficult to identify. Because of this and not

\footnotetext{
${ }^{1}$ A previous version of this paper has been presented at the conference "AISSEC: 16 National Scientific Conference", Parma, 21-23 June 2007. We would like to thank Renzo Bianchi, Federico Cingano, Piero Cipollone, Andrea Ginzburg, Enrico Rettore and Marco Valentini whit whom we discussed various aspects of the study with. Thanks once again to Marco Valentini and Federico Cingano for their help in obtaining and processing data, not forgetting the Treviso Chamber of Commerce for their assistance regarding the questionnaire.
} 
because 'light' integration is unimportant, international trade experts have not really taken it into consideration (Bugamelli, Cipollone and Infante, 2000).

In Italy the little analysis available seems to point out the traditional sectors and sectors characterised by important economies of scale as being less present in overseas markets and holding minor investments compared with the high-tech sectors. This result contrasts with anecdotal evidence according to which the delocalization of textile, clothing and footwear sectors is highly relevant (CEPS, 2005; Gomirato, 2004; Grandinetti, 2006; Graziani, 1998; 2001) but occurs in the mild forms mentioned before. For example, within traditional sectors there has been a steady and substantial increase of the number of firms that have established trade agreements with overseas partners (Bugamelli, Cipollone and Infante, 2000). A wide study regarding Italian manufacturers with more than ten employees, for the period 2000-2003, reveals the well known fact that the large majority of Italian firms export abroad (70 percent of the total) and the majority of them has kept up or started trade operations or overseas trade agreements with foreign correspondents, with a marked increase over the previous period (Capitalia, 2005). Direct investment involves a limited number of businesses, while much more firms have set up technical collaboration agreements with overseas companies (Capitalia, 2005, Tables D16bis and D30).

This paper aims at investigating production outsourcing abroad of the Veneto footwear and clothing industries. It is based on information available from a direct survey combined with individual budget data. The survey takes into account outsourcing carried out both through direct investments, subcontracting and partnership and measures outsourcing with respect to the quota of the final product manufactured abroad: the various forms in which the value chain is organized is taken into account but it is not considered of direct relevance to the present investigation.

The decision to outsource part of the production abroad reflects in a positive variation in the level of activity and in gross profits. This analysis shows the importance of relocation on a global scale in order to give new competitivity to Veneto firms in a sector which in the 80s resorted to domestic subcontracting and since the mid 90s, after the abandonment of the Lira traditional weak rate of exchange, is looking for new competitive strength through the delocalization of production to countries with low labour costs.

\section{The international organization of manufacturing in clothing industry}

Since the 90s various industrial sectors have been characterised by an increase in the international fragmentation of production in. This is the result of the gradual reorganisation of the production 
sequence, on an international basis, promoted by an ever-increasing number of businesses which extend their production processes outside their country of origin. International segmentation allows a higher degree of specialisation within the value chain and shows in an increase in trade, since many intermediate or semi-manufactured products obtained from manufacturing abroad are then reimported to be completed or distributed by the final producers, increasing international trade flows ${ }^{2}$. Over the past fifteen years many European businesses have moved part of their productive processes to East Europe and China whose markets are well underway. This has opened up new and interesting markets, and in addition has offered production locations at a particularly low cost ${ }^{3}$.

In East Europe, in clothing and footwear in particular, the management of the value chains based on sub-contracting prevails over direct investments because of the relatively simple processes which could be carried out abroad, the low transport costs and the skills available in many of these countries. Small and medium Italian manufacturers in traditional sectors are not able (from an organisational and financial point of view) to undertake complex operations such as setting up agreements regarding new products and production technologies, few of them have made direct investments in overseas markets, but the majority have created a dense network of subcontracting relations with foreign companies in order to manufacture slices of the value chain under their surveillance and at a low cost.

In the 90s the gradual elimination of trade barriers has encouraged the reorganisation of the productive cycle of clothing and footwear firms on an international basis and has fostered investments between industrialised and developing countries (Baden, 2002). As far as Europe is concerned, we should mention the ATC (Agreement on Textiles and Clothing), signed by countries in the E.U. belonging to the World Trade Organisation in 1995 which stipulated gradual total liberalisation of restricted imports, completed in January 2005 with the end of the Multifiber Agreement which controlled the international market of textile products since 1974. Since the 90s more and more European companies have exploited the outward processing trade tariff regime negotiated in 1986, 1992, 1994 and 1995 by the European Union with Centre-Eastern Europe and the Mediterranean which have allowed E.U. countries to export raw materials, subsequently reimporting the finished products as compensation at no cost. The interest of companies in this type of trade has gradually slackened off following the growth of the E.U. which now includes some of the countries involved while others will be joining in a few years.

\footnotetext{
${ }^{2}$ Disintegration at the global level implies an upsurge in trade flows, as many intermediate commodities are exchanged across national borders (Feenstra, 1998).

${ }^{3}$ The cost is the highest priority element according to all surveys concerning firms in the traditional sector, but the tax benefits relative to setting up companies overseas proves also very important. Regarding the latter, Stevanato (2004). See Bénassy-Quéré, Fontagné and Lahrèche-Révil (2005) on how different tax legislation directs the flow of direct investments.
} 
Most Italian clothing manufacturers have relocated abroad using international subcontractors. These companies had already delegated many production phases to Italian outworkers often located near the final producers in a territorial network of specialized suppliers, the district. This form of industrial organization is centred on the exploitation of phase economies (Brusco, 1989) based on domestic fragmentation of the productive cycle. For example in the clothing sector cutting, sewing, stitching and pressing are often outsourced, while in the footwear sector stitching is typically subcontracted. Setting up a workshop is relatively easy and inexpensive since the initial requirements (a simple technology and availability of skilled workers) are low, but they gradually increase as other production phases are included in the outsourcing flows. Phases at the beginning or at the end of the production chain sometimes require sophisticated machinery for cutting, washing, dyeing and printing ${ }^{4}$ and, in footwear, for the production of uppers and moulded soles.

The choice made to produce in a low wages country - but keeping fixed quality standards - is function of the ability of the available workforce and of the technological level of the production procedures. Initially the least complex phases of production are outsourced and resources concentrate on the training necessary for a few specific tasks. In most cases international production is set up by the leading firms of the industrial countries that have no direct production activity brand-driven commodity chains according to Gereffi (1999). These are well established brands or trading companies which build up and coordinate sometimes huge international production networks that cover a large number of countries with low labour costs. However, the leading Italian clothing and footwear industries that have delocalised in recent years have not abandoned domestic production and usually keep a sometimes relevant quota of production at home (weaving, dyeing, flash collections and re-orders, high quality leather shoes) ${ }^{5}$.

A production cycle already segmented domestically is easily relocated abroad. In some cases production is exclusively focused on agreements with local manufacturers, which foresee the purchase by the Italian company of a final product made with raw materials acquired in the place of production, a full-package relation. This relation is used in dealing with Asian suppliers due to the fact that good quality raw materials and top quality accessories are locally available, and efficient production networks organised by local intermediaries take care of production coordination (Gereffi, 1999; 2002). In all those situations where low labour costs countries are not far away from

\footnotetext{
${ }^{4}$ Sometimes big brands, just soon after setting up delocalization, face bottlenecks in the sequence of phases in which the production process has been sliced and resort to direct investments in order to complete the process. In several occasions, Italian clothing brand have set up industrial laundries, cloth printing facilities etc., in order to manufacture the entire production cycle abroad. In this way, a complex production can be entirely manufactured abroad with increased efficiency in the management of the value chain. See Crestanello and Tattara (2006).

${ }^{5}$ Therefore the Veneto companies differentiate from the Gereffi type (2002) where the brands have delocalized almost the entire production. There are numerous examples, from Benetton to Stefanel, Diesel, Marzotto, just to mention a few. See Owen (2001) for a more complete view on this topic.
} 
the location of the industrial brand, as it happens with Central-East Europe and North Africa, have a relatively weak industrial structure and don't possess the necessary elements to complete all the parts of the productive process, production outsourcing develops into a semi-manufacturing relation: the brand supplies fabric, leather and accessories and subcontracts some production phases on its detailed specifications then re-importing the finished product (Crestanello and Dalla Libera, 2003).

The brand manages the complex relations between each unit of the process, coordinates to a greater or lesser degree the people involved and often makes the necessary controls with its own personnel (Gereffi, Humphrey and Sturgeon, 2005).

\section{The deverticalization of Veneto clothing industry, domestic subcontracting and international relocation}

The Veneto is a region of the Italian North-East of 4.6 millions inhabitants, specialised in light mechanics, textile-clothing, furniture and footwear productions. In the year 2001 a hundred thousands employees worked in the textile-clothing-footwear sector, 24 percent of the total employment in manufacturing; the sector maximum expansion dates from the 70s and was accompanied by the creation of a large number of small and medium-size firms. In the following decade growth continued at a slower pace and there was a general reorganization; large businesses faced increasing economic difficulties and many firms outsourced domestically significant phases of the productive process that in the more recent years have been transferred abroad. The biggest and well-known clothing firm in Veneto, the Benetton Group, is a clear example of the strategy set in motion by many Veneto firms during the last 30 years. The Benetton Group can be considered an extreme case of vertical integration as it included, from the very beginning, the retailing side by side with manufacturing and, at the same time, has been characterized by a strong tendency towards outsourcing, initially involving a large number of small local domestic producers (Nardin, 1987, p. 91), but turning rapidly in recent years towards foreign subcontractors (Crestanello and Tattara, 2007).

The alternative phases of product outsourcing domestically and abroad can be clearly described looking at the employment variations in clothing firms, brands and small laboratories during the last three decades. The situation regarding employment in the Veneto clothing sector is detailed on the basis of VWH data (Veneto Worker Histories) processed by Venice University (Figure 1) although we must keep in mind that - beside registered employment - the sector is 
characterised by a large number of workers 'under the table', estimated to be one fifth of total employment ${ }^{6}$.

The clothing sector, studied in the four principal provinces, Verona, Vicenza, Padova and Treviso, strictly limited to garment manufacture $\left(\csc ^{7}: 10801,10803,10805\right)$ and to knitwear (csc: 10713), had about 65,000 employees in 1980. During the following decade employment increased rapidly reaching a total of 78,000 in 1990, but the increase was concentrated in local small artisan units which doubled their employment (plus 92.7 percent) with 17,000 more workers. In large firms employment declined of more than 12 percent corresponding to a loss of 5,500 jobs. According to a national survey carried out in 1993 by Confartigianato, two thirds of clothing companies worked as subcontractors, thus employing more than half of the workers in the sector. The national clothing industry is characterised by big regional differences and the Veneto has a particularly dense network of subcontractors consisting of small firms (ten workers on average) which work almost exclusively for the final producers that have their headquarter in the region (Crestanello, 1999, pp. $16 \mathrm{ff}$.). In the mid-nineties subcontracting in clothing in Italy employed a third of all subcontracting workers in the sector in Europe (EC, 1996, Table 1). The fall in employment by bigger firms has brought about a process of disintegration of the final product to such an extent that 'now many large firms have delocalized all production processes keeping only planning and marketing in the main firms' (Crestanello, 1999, p. 18).

In the nineties (1991-2001) the situation reversed. Small artisan firms lost nearly all the workers they had acquired in the previous decade. Moreover final producers lost a further 11000 jobs. In 2001 people employed in this sector in our territory totalled only 49 600, 36 percent less than eleven years earlier. A result of the fact that most production was taking place abroad ${ }^{8}$.

The Veneto textile-clothing-footwear sector has been anyway progressing steadily through time, at least till the year 2000: the regional value added, together with exports, increased considerably in real terms during the nineties even if at a lower average rate compared to the previous decade (Figure 2). Faced with the job loss which hit the sector starting from 1991, the value added continued to rise with an unchanging trend until 1997, then remaining more or less the same until 2001 and finally fell sharply in 2002, due to a general crisis in the sector ${ }^{9}$. Productivity measured by value added per capita notably increased: this was because part of production moved

\footnotetext{
${ }^{6}$ Referring to Italy in 1992, The European Commission estimated work 'under the table' in the clothing industry to be 21 percent of overall employment. EC, 1996, Table 2. Therefore, a widespread phenomenon.

${ }^{7}$ Acronym for contributive statistic code.

8 The role of the Veneto within the sphere of outsourcing in 'traditional' sectors was pointed out by Schiattarella in 1999 and subsequently has been widely confirmed. The Capitalia survey shows, referring to traditional sectors, that 61 percent of companies based in the North-East completely delocalized production to countries with low labour costs over the past three years, compared to 46 percent at a national level.

${ }^{9}$ Istat and INPS data are similar regarding the fall in employment. In the nineties in the Veneto, the decline was above the national average.
} 
abroad with a drastic drop in domestic employment while the value of production did not significantly diminish. In fact, in those years profits of final producers - in particular medium-size firms - showed a steady improvement ${ }^{10}$.

Summing up, we can quite clearly outline three periods. The first period involved the growth of the sector with an increase in small and medium-sized firms and the creation of the Veneto clothing industrial district (sixties and first half of the seventies). In the second period the development of subcontractors prevailed, mostly localized within the district (the 80s): the number of small laboratories rapidly increased and employment grew. While in the third period subcontracting shifted abroad, either through direct investments or foreign firms, and many domestic laboratories were forced to close down. This last move brought about a drop in employment and a notable increase in per capita value added at a regional level (90s).

Fig. 1 - Employment in clothing according to firm type in Veneto

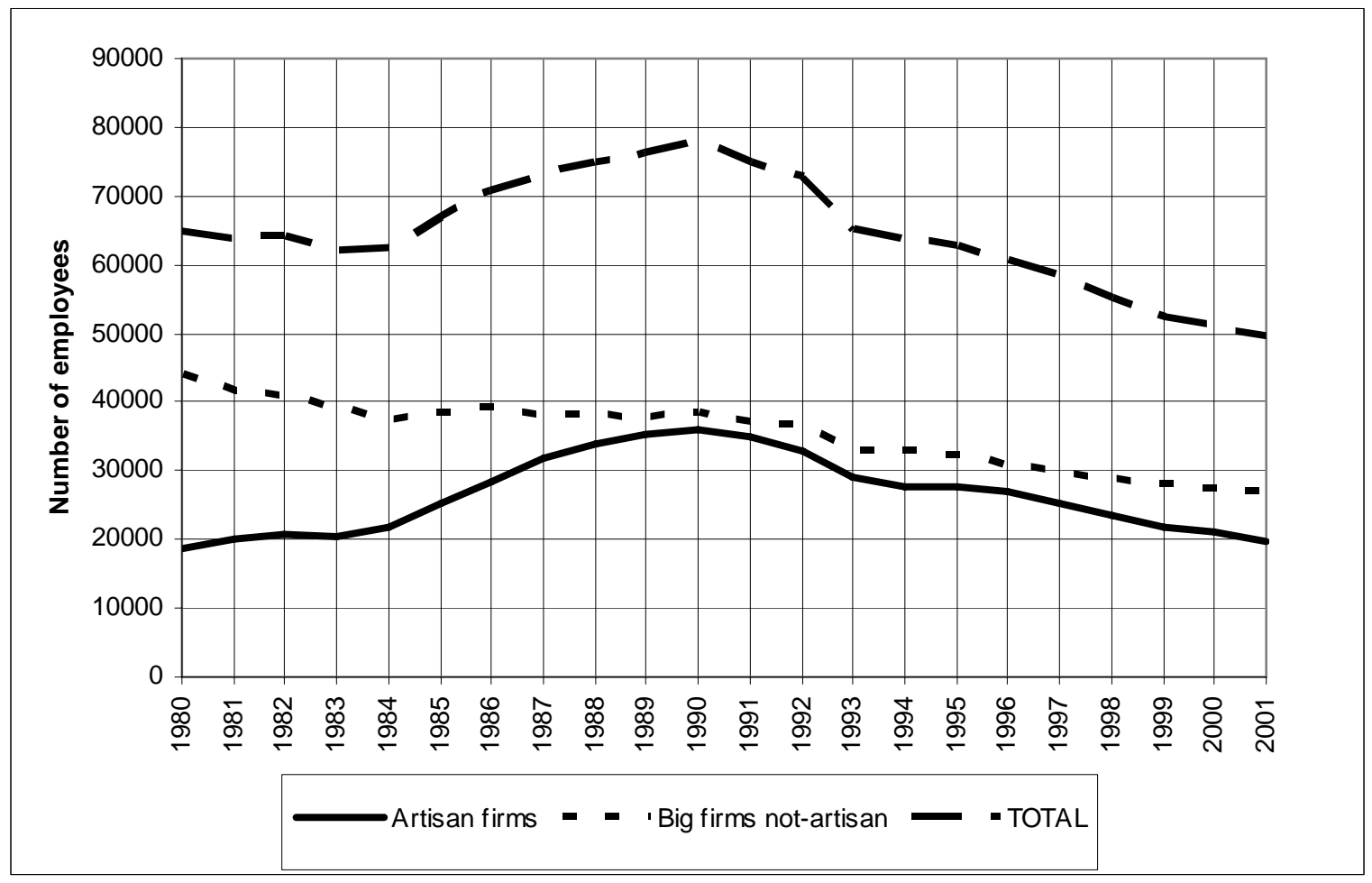

\footnotetext{
${ }^{10}$ Between 1996-2000 the value added of the final producers of footwear and clothing in the North-East, calculated from average-size joint stock companies, went up by 12.5 percent, compared to a much lower overall increase, while unemployment went down by 1.6 percent (Mediobanca - Unioncamere, 2003).
} 
Fig. 2 - Value added at constant prices in textile-clothing-footwear and employment, in Veneto

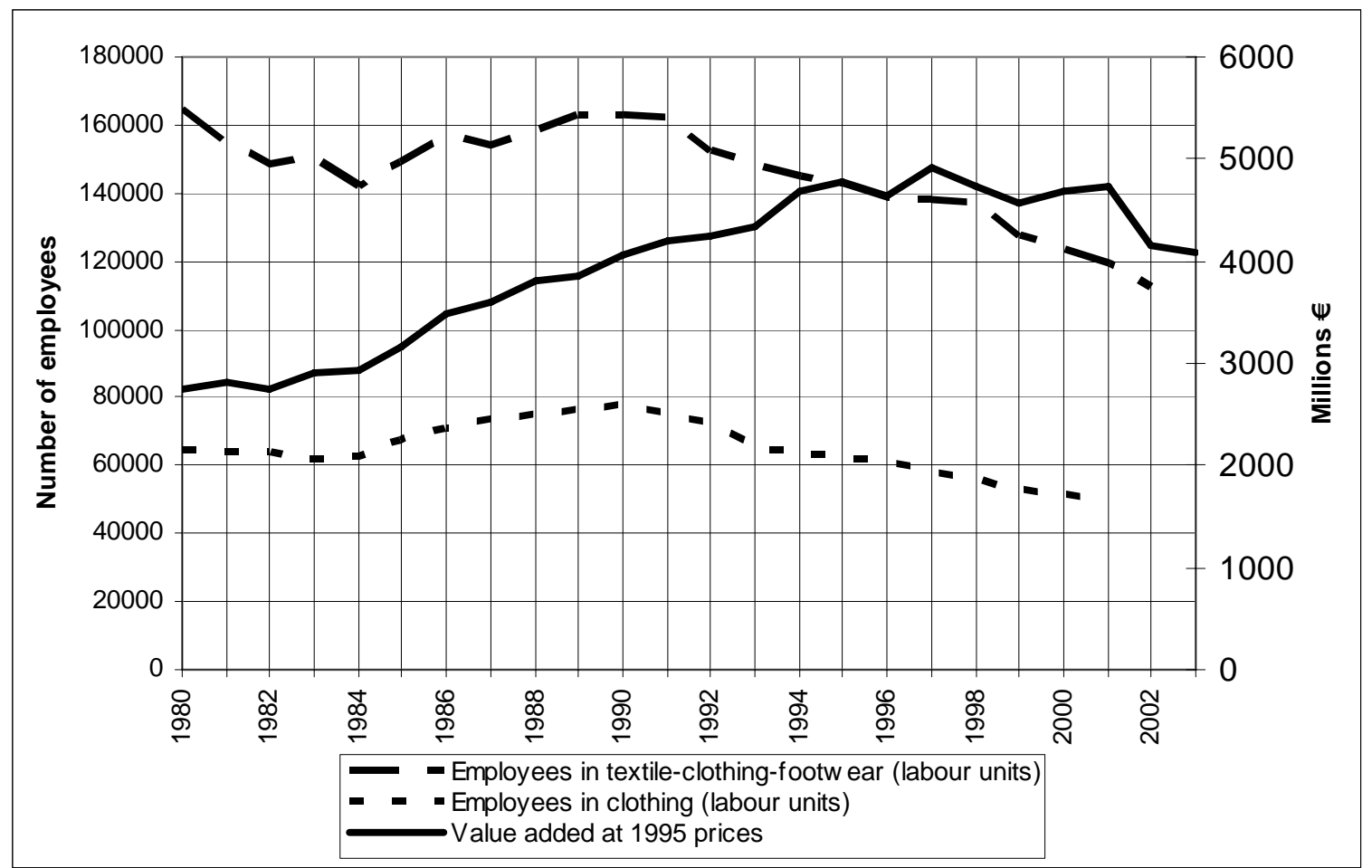

Source for Figures 1, 2: VWH, db Veneto, regional account data for 1980-1995 and www.istat.it for 1996-2003

\section{The effects of outsourcing}

The significant change that occurred in firm's structure, similar to what we have seen over the past decades, can be illustrated by way of a simple numeric example. The three possibilities examined are: integrated production processes, a final firm with national subcontracting, and a final firm with overseas subcontracting (see also Gordon, 2004). The example reports values which reflect the average magnitude occurring in the Veneto clothing sector around 2003, while foreign subcontracting refers to Romania. The per capita labour cost equals one for the final producer, drops to 0.8 for a national subcontractor and goes down to 0.2 in the case of an overseas subcontractor ${ }^{11}$. The value of the turnover of an Italian subcontractor is divided into 50 percent for salaries and 50 percent for expenses in order to purchase intermediate materials which the subcontractor buys or receives from its customer. In the case of the Romanian subcontractor the ratio is 25 percent for salaries and 75 percent for intermediate materials (for footwear the proportion for raw materials is slightly higher, see Crestanello and Tattara, 2006). Let's assume for simplicity’s

\footnotetext{
${ }^{11}$ Labour costs in the clothing sector in Romania total about one eighth of the cost in Italy, even if this varies greatly (see note 13). In the example we use a value of about 25 percent adding other costs relative to outsourcing (transport, training etc.).
} 
sake that the final producer relocates abroad by sending materials of the same value as those used previously in Italy. The structure of the production processes is shown in its basic terms in Table 1.

Tab. 1 - Structure of the production in an integrated and in a deverticalized firm

\begin{tabular}{|c|c|c|c|c|c|}
\hline & \multirow{2}{*}{$\begin{array}{l}\text { Integrated } \\
\text { producer }\end{array}$} & \multicolumn{2}{|c|}{ National subcontracting } & \multicolumn{2}{|c|}{ Foreign subcontracting } \\
\hline & & Final firm & Subcontractor & Final firm & Subcontractor \\
\hline Turnover & 1000 & 1000 & 500 & 1000 & 410 \\
\hline Cost of labour & 650 & 300 & 280 & 300 & 100 \\
\hline Row materials & 200 & - & 200 & - & 300 \\
\hline Semi-manufactured & - & 500 & - & 410 & - \\
\hline Gross profits & 150 & 200 & 20 & 290 & 10 \\
\hline Unit cost of labour & 1 & 1 & 0,8 & 1 & 0.2 \\
\hline Employees & 650 & 300 & 350 & 300 & 500 \\
\hline Value added & 800 & 500 & 300 & 590 & 110 \\
\hline
\end{tabular}

From a value chain perspective we can consider the domestic and the overseas units as separate plants belonging to the final producer. How the overall profit is shared between the final producer and the subcontractors depends on the price at which semi-manufactured goods are transferred (in the case of FDI) or purchased (subcontracting), hence on the final firm relative power, on its targets and on various fiscal regimes. The experience resulting from several visits to subcontractors working in Romania in the clothing sector, leads us to believe that the final producer is able to keep the subcontractors' profit to a minimum, owing to some guarantees concerning quality and reliability ${ }^{12}$. In synthesis in Table 1 we end up with a profit of 150 in the case of integrated production, of 200 in the case of national fragmentation, and of 290 in the case of overseas fragmentation.

Relocation abroad is usually carried out by firms which had already fragmented their production delegating some parts to local subcontractors so that going abroad involves much fewer risks and doubts (for a theoretical example see Melitz, 2003). In this case the impact of relocation on the final producer is obtained by comparing the values in column three to that in column five: the lower cost of overseas subcontractors compared to the national equivalent increases profits. The increase shows the benefits gained by the final producer to utilise this new corporate strategy ${ }^{13}$.

\footnotetext{
12 The companies have strict control over their subcontractors in Romania and the sub-contractor functions as a delocalized sector of the client's factory. In the case of delocalization towards Asia, package relations are prevalent and the subcontractor acquires raw materials and accessories and produces the final product, accepting the risks involved.

${ }^{13}$ In reality it is widely believed that productivity in Romania is lower than in the Veneto and this brings about an increase in employment which is, however, slight and doesn't alter the meaning of the example (Table 1). See also Crestanello and Tattara, 2006.

This measure has nothing to do with productivity calculated by relating the value of the product to the number of employees which is often mentioned in international publications. This method is not a technical estimate of efficiency
} 
Many firms transferred abroad part of the machines used domestically; several Italian subcontractors in clothing and footwear productions were pressed to move abroad by their customers in order to reduce costs, particularly in Hungary and Romania but also in Tunisia. The large number of Veneto small firms set up in Romania, in Timisoara, make economic commentators to currently refer to Timisoara as to the eighth Veneto province.

The impact of overseas delocalization should be evident in the final firm budget data, although the shift from a numerical example to enterprise balance sheet figures cannot be direct and is not without risks. Therefore we are waiting for the delocalized processes to have a positive effect on turnover and the gross earning (EBITDA ${ }^{14}$ ) for final producers. The gross operative earning of the final producer increases shifting from integrated production to domestic subcontracting and then to overseas subcontracting, owing to reduced labour costs. This increase shows the benefits gained by the final producer to utilise this new corporate strategy.

In the majority of cases examined in our study the decision to carry on abroad part of production is associated with an increase in the level of activity. Production increases both because the decision to govern a value chain with productive units operating in different countries is feasible only in the presence of larger productive volumes and because the decision to outsource abroad is expected to reduce unit costs, promoting a more aggressive policy and larger sale volumes.

The definition of a new corporate strategy that brings about important changes regarding the value chain like those we are discussing, is often combined with a firm's repositioning at the higher levels of the chain that involves new management roles and an increase in qualified staff responsible for the governance of this more complex strategy. All this can complicate the overall analysis and introduce new variables which we are only partially able to account for.

Figures 3 and 4 graphically represent the trend over time of turnover and EBITDA of four Italian companies with reference to the main relocation event (dotted line). If overseas outsourcing were a pure substitution effect (from domestic to overseas), turnover would not be affected while the effect on EBITDA might be positive, reflecting the decline in labour cost of production. A positive result for both, turnover and EBITDA means a large volume of activity and larger profits as well.

but the result of how production chains are organized and therefore of the proportion between the value imputed to semi-manufactured and to finished goods in the relations within the chain. In fact, productivity measured as the ratio between value added and number of employees regarding the Romanian clothing-textile sector hardly totals 14 percent of the 15 EU countries' production, according to standard purchasing power. See: Ceps-WIIW (2005), Table 4.

${ }^{14}$ Earnings Before Interests, Taxes, Depreciation and Amortization. 
Fig. 3 - Turnover in four companies (in thousands of Euros, current prices)
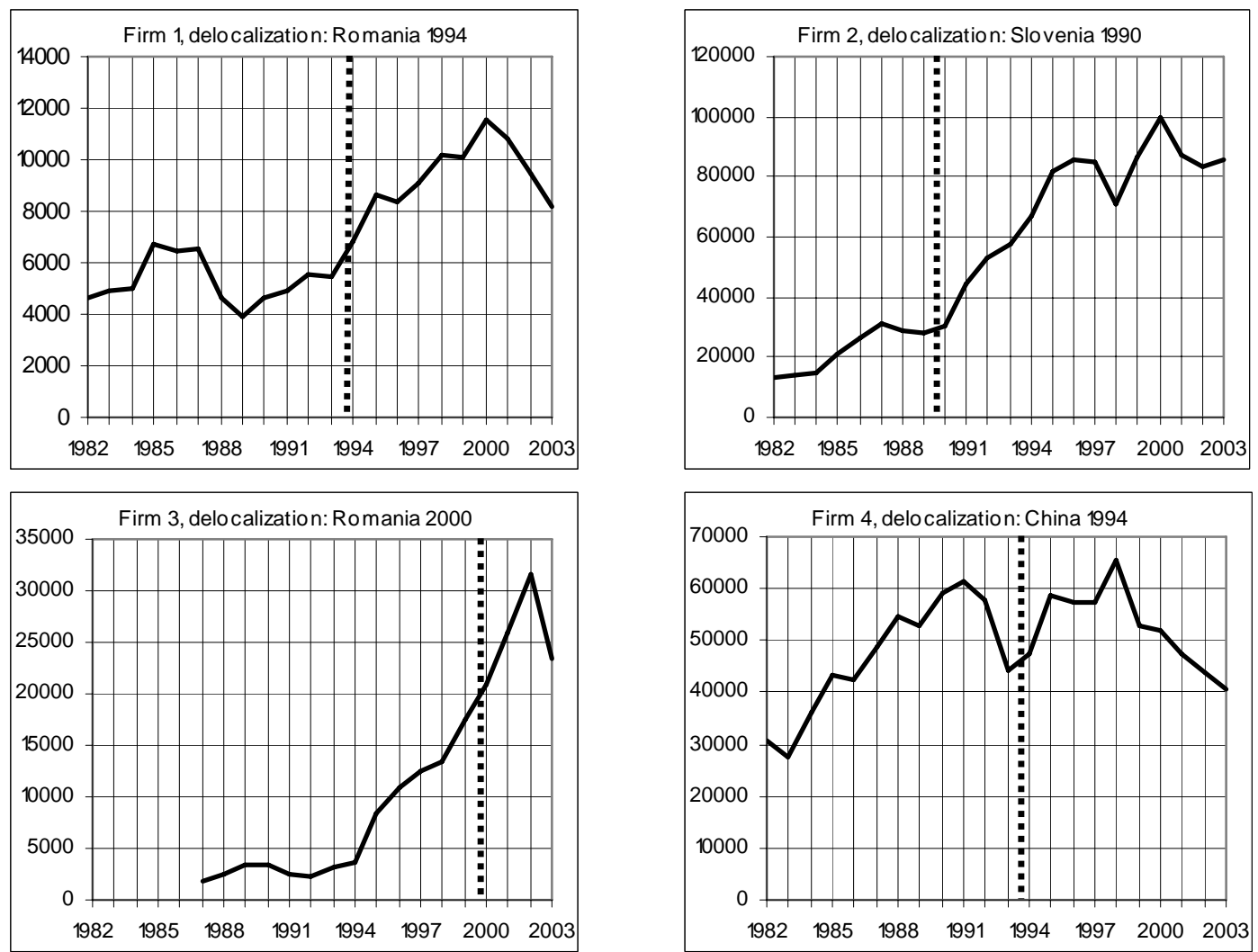

Source for figures 3, 4: company balance sheets, Veneto Chambers of Commerce

Fig. 4 - EBITDA in four companies (thousands of Euros, current prices)
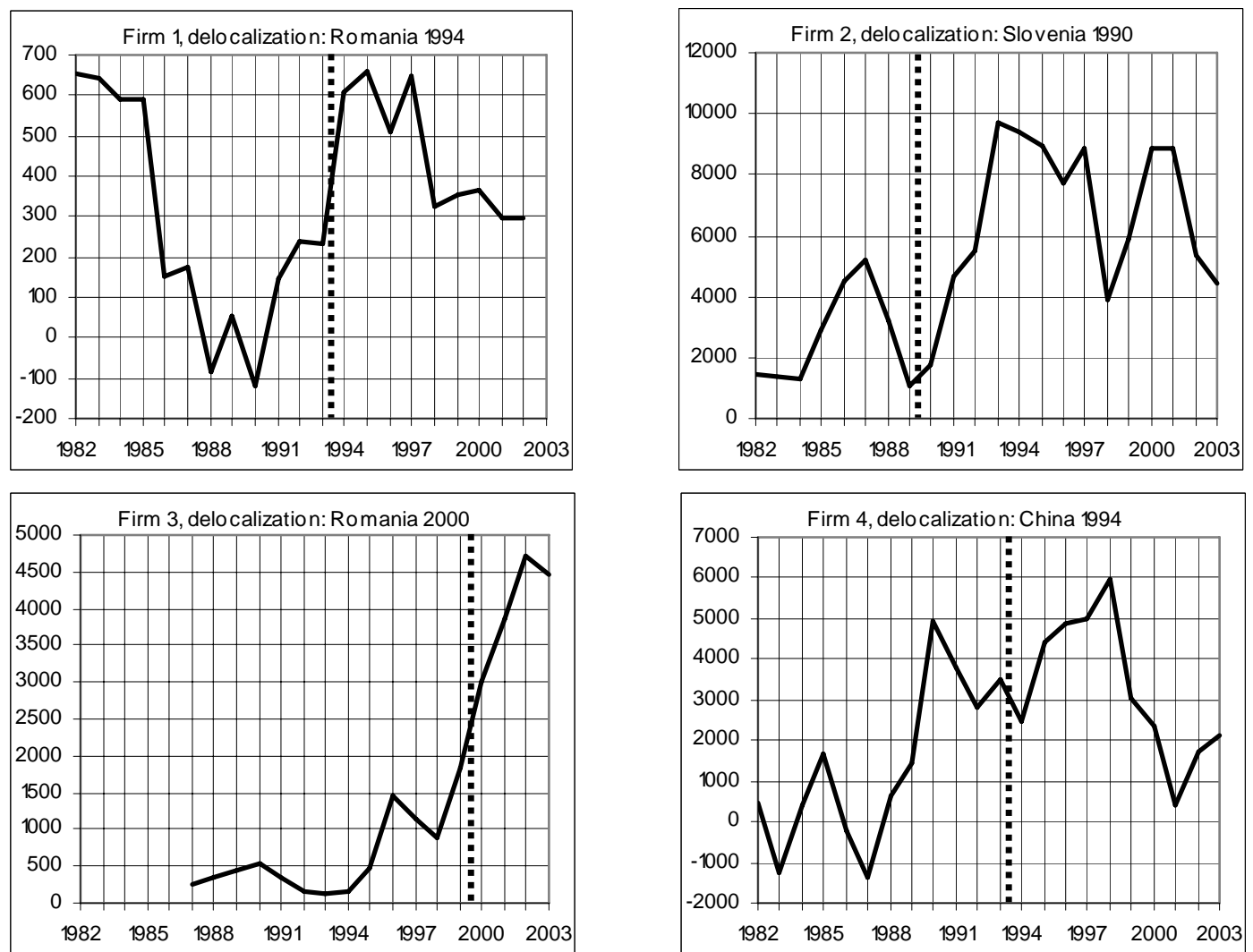


\section{The estimates}

In order to verify if the delocalized processes has a positive effect on gross profits and turnover in the final firm, and if the effect turns out to be higher according to the quota of the products which a firm produces abroad (out of the overall total) we have estimated a linear regression model using panel data referring to the group of firms studied.

The analysis has been carried out on a self-selected group of 70 limited and joint stock companies based in the Veneto involved in the clothing and footwear sector on 31 December 2003 (Appendix). They are mainly medium-size companies, employing overall 7,700 workers, which have delocalized some important production phases abroad. They represent more than 30 percent of the total employment of the companies with more than 50 employees operating in the textile, clothing and footwear sector in Veneto in 2001, according to the Industrial Census; less than half of them internationalised production through direct foreign investments (and possible subcontracting), the majority resorted to subcontracting to foreign firms. The model's estimate is built on budget data from the Veneto Provincial Chamber of Commerce collection, employment data from the VWH database, data on outsourcing from a questionnaire delivered to each company and supplemented by several telephone interviews. Keeping in mind that overseas production is a phenomenon which started in the mid-eighties, we extended the data collection from 1982 to 2003. Some companies included in the analysis began their activity after 1982 and therefore the panel is unbalanced.

Information on outsourcing regarding each company was acquired from a direct survey carried out at the beginning of 2004 and refers to the previous year (Gianelle, 2005). For each delocalization (direct investments, subcontracting to foreign firm etc.) the starting year, the country involved and the type and intensity of the relation ${ }^{15}$ are known. The latter is computed as the ratio of goods produced abroad to those made at home, and is taken into account if it is larger than $10 \%$ of the overall production. Outsourcing is limited to one episode for each company, the most significant in terms of number of delocalized commodities ${ }^{16}$.

The companies making up the panel vary in size, type of market involved, export trends, type of production phases carried out domestically and individual background. Diversity is taken into account by a group of omitted structural variables, specific for every company and constant over

\footnotetext{
${ }^{15}$ Outsourcing can involve direct investments, subcontracting etc, but here we make no distinction. Each example of delocalization defined by its first year and the country involved can also be characterized by a range of manufacturing links with different companies situated in the same country. This aspect is not relevant as far as our analysis is concerned because all the companies in the same country have similar costs. Therefore we consider relations with each foreign country (for example Romania, Tunisia and China) as a single occurrence.

${ }^{16}$ Some companies have several delocalized activities in various countries, set up in different years, involving various productive volumes. In this survey we take into consideration the main delocalization event.
} 
time, and the effect of diversity is taken into account by estimating a fixed-effect regression (Hsiao, 2003).

The dependent variable of the model is alternately the turnover at current prices and the gross earning before taxation (EBITDA) both expressed in logarithms ${ }^{17}$. The latter is provided by the difference between the operative value added and labour costs in current terms.

The impact of outsourcing abroad can be estimated by means of a dummy which splits the time period referred to each company into two sub-periods: before and after the event. Delocalization occurs, for various companies, in different years within the time span studied and this allows the impact of the variable to be identified. The delocalization dummy, which estimates the average effect of relocation, can interact with a linear temporal trend, resulting in a delocalization variable that captures the growth effect of relocation. The impact of outsourcing is therefore estimated, on average, by the coefficient of these two delocalization dummies, henceforth 'average effect' and 'growth effect'.

In Figure 5 the horizontal axes measures the distance in years in relation to the year of delocalization $t_{d}$ that is labelled zero. The drift of the continuous function represents the average impact effect, while the difference in the dotted line' slope represents the growth effect.

Fig. 5 - Impact of relocation

EBITDA, TURNOVER

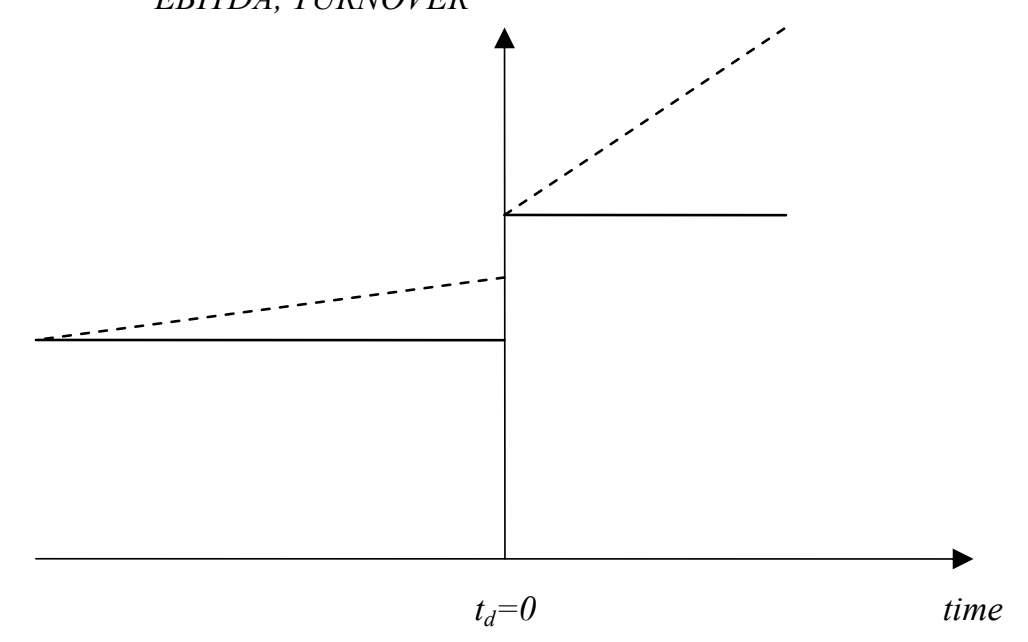

${ }^{17}$ Negative values of the EBITDA, for which the logarithm does not exist, are treated as missing values. 
The constant delocalization dummy $D c$ (average effect) is defined as follows, where $t_{d(i)}$ is the year of relocation for firm $i$

$$
D c_{i t}=\left\{\begin{array}{cc}
0 & \text { for } t<t_{d(i)} \\
1 & \text { for } t \geq t_{d(i)}
\end{array}\right.
$$

The trend delocalization dummy (growth effect), which is assumed to be linear, is defined by making a linear temporal trend interact with the preceding dummy, obtaining the variable $T D c$. Hence the regression estimated with reference to turnover is

$$
\log T u r n_{i t}=\beta_{0}+\beta_{1} D c_{i t}+\beta_{2} T D c_{i t}+\beta_{3} E_{i t}+\beta_{4} \operatorname{Ord}_{i t}+\gamma_{t}+u_{i}+\varepsilon_{i t}
$$

Turnover and EBITDA are regressed on the firm's employment level, Emp and a set of other controls in order to take into account cyclical factors, demand, price and technological progress, provided they involve all firms to the same extent in the same years. With the aim of taking into account cyclical trends ${ }^{18}$ we have included among the independent variables an index of sector orders at the international level, calculated by Istat on a monthly basis ${ }^{19}$, $\mathrm{rd}$. The year variables $\gamma$ are year dummies, that is variables which include events involving all companies in the same way in a specific year and therefore show the influence of sector specific shocks (inflation, average growth in the sector, etc.) on the dependent variable. They do not prevent the identification of the delocalization dummy because the relocation events occur in different years.

Some caution is necessary: available data don’t allow to take into account firm's specific effects like those deriving from a change in the type of product or market trends, neither the evolution of productive organization and changes in relations to other companies in the production sequence; as these elements are possibly correlated with outsourcing, the results can be blurred.

A visual presentation of the outsourcing impact is obtained by reproducing Figure 6 through our data. A regression of the two dependent variables $\log$ Turn and $\log E B I T D A$ on control variables (year dummies, firm dummies, employment, orders) is estimated in order to get rid of them. In Figure 6 the vertical axes measures the yearly average residues of the regression in relation to time, and represents the net effects of relocation clear of yearly, company, sector specific shocks. Time is centred on the delocalization event and Figure 6 is immediately comparable with previous Figure 5.

\footnotetext{
${ }^{18}$ See Heckman (1985) who suggests checking for the economic cycle.

${ }^{19}$ The sales confidence index is sector specific. The sectors and corresponding indexes are based on the three digits Ateco 2002 classification (DB177, DB182 and DC193).
} 
Fig. 6 - Residuals of the regression of $\log$ Turn (left) and $\log E B I T D A$ (right) over controls
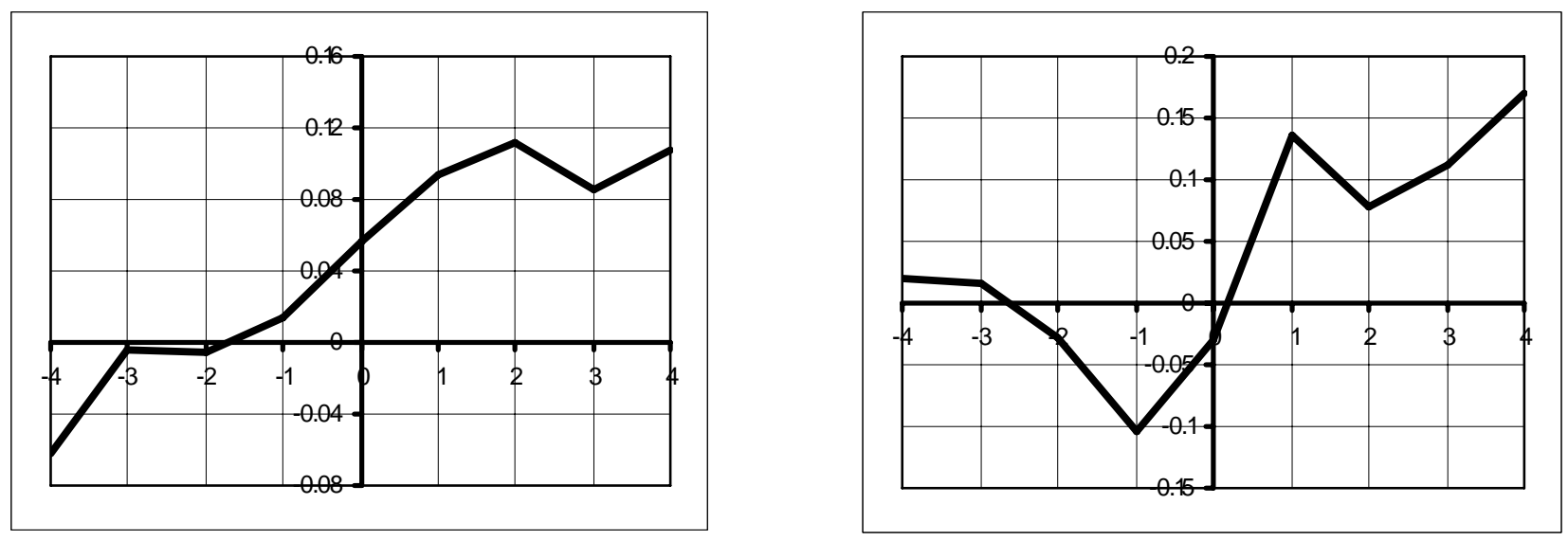

Figure 6 makes clear that some firms have delocalized abroad after a drop of EBITDA. A rather reasonable result, that explains the firm's decision for a new strategy and that nonetheless requires caution in interpreting the coefficient estimates, firms in fact self-select into treatment: some firms delocalize abroad after a negative profit shock and this can make the average delocalization result - measured by the coefficient of the dummy variable of interest - to be overestimated if reported to the entire population (can be considered a case of omitted variables as well, as we are not able to depict firms heterogeneity: Heckman and Smith, 1999). In the present work we are using a self-selected sample of firms - only firms which delocalized abroad are considered - but, in the last decade, delocalization has been a strategy largely pursued by the main clothing and footwear medium-size Veneto firms and firms that did not delocalize are very rare; so that we believe the estimates we are presenting provide a reliable measure of the 'general' impact effect of delocalization.

Estimates results (Equation 1, Tables 2 and 3, col. 2) show a remarkable average effect both on the value of turnover and on the EBITDA. On average, the delocalization impact is 16 percent on turnover, and 18 percent on EBITDA: the larger volume of activity is paralleled by larger profits. The growth effect is declining and very small in the case of turnover, telling us of a possible setback just following the outsourcing decision and it is not significant in the case of EBITDA. 
Tab. 2 - Effects of outsourcing on turnover (Equation 1)

\begin{tabular}{|c|c|c|c|c|c|}
\hline \multicolumn{6}{|c|}{ logTurn } \\
\hline & & 1 & 2 & 3 & 4 \\
\hline Average impact & $D c$ & $\begin{array}{l}0.1693 * * * \\
(0.0419)\end{array}$ & $\begin{array}{l}0.1588^{* * *} \\
(0.0418)\end{array}$ & & \\
\hline Growth impact & $T D c$ & & $\begin{array}{l}-0.0238^{* * *} \\
(0.0091)\end{array}$ & & \\
\hline Average impact through quota & $Q D c$ & & & $\begin{array}{l}0.2440 * * * \\
(0.0734)\end{array}$ & $\begin{array}{l}0.2847 * * * \\
(0.0743)\end{array}$ \\
\hline Growth impact through quota & $Q T D c$ & & & & $\begin{array}{l}-0.0374^{* * *} \\
(0.0130)\end{array}$ \\
\hline Employment & Emp & $\begin{array}{l}0.0018^{* * *} \\
(0.0002)\end{array}$ & $\begin{array}{l}0.0018 * * * \\
(0.0002)\end{array}$ & $\begin{array}{l}0.0018 * * * \\
(0.0002)\end{array}$ & $\begin{array}{l}0.0018^{* * *} \\
(0.0002)\end{array}$ \\
\hline Sector orders & Ord & $\begin{array}{l}0.0174 * * * \\
(0.0022)\end{array}$ & $\begin{array}{l}0.0175 * * * \\
(0.0022)\end{array}$ & $\begin{array}{l}0.0173 * * * \\
(0.0022)\end{array}$ & $\begin{array}{l}0.0178 * * * \\
(0.0022)\end{array}$ \\
\hline Yearly dummies & $\gamma$ & Yes & Yes & Yes & Yes \\
\hline Firm’s specific effects & $u$ & Yes & Yes & Yes & Yes \\
\hline $\mathrm{N}^{\circ}$ of obs. & & 1138 & 1138 & 1138 & 1138 \\
\hline $\mathrm{N}^{\circ}$ of firms & & 70 & 70 & 70 & 70 \\
\hline $\mathrm{R}$ - Squared within & & 0.5614 & 0.5645 & 0.5609 & 0.5645 \\
\hline
\end{tabular}

Notes for Tables 2, 3 and 4: period of observation 1982-2003. All the regressions include specific firm intercept for each company and year dummies. Robust standard errors in brackets. ***: significance $1 \%$, **: significance $5 \%$, *: significance $10 \%$.

Tab. 3 - Effects of outsourcing on EBITDA (Equation 1)

\begin{tabular}{|c|c|c|c|c|c|}
\hline \multicolumn{6}{|c|}{$\log E B I T D A$} \\
\hline & & 1 & 2 & 3 & 4 \\
\hline Average impact & $D c$ & $\begin{array}{l}0.1772 * * \\
(0.0767)\end{array}$ & $\begin{array}{l}0.1784^{* *} \\
(0.0763)\end{array}$ & & \\
\hline Growth impact & $T D c$ & & $\begin{array}{l}0.0032 \\
(0.0157)\end{array}$ & & \\
\hline Average impact through quota & $Q D c$ & & & $\begin{array}{l}0.1682 \\
(0.1226)\end{array}$ & $\begin{array}{l}0.1639 \\
(0.1262)\end{array}$ \\
\hline Growth impact through quota & $Q T D c$ & & & & $\begin{array}{l}0.0037 \\
(0.0255)\end{array}$ \\
\hline Employment & $E m p$ & $\begin{array}{l}0.0016 * * * \\
(0.0005)\end{array}$ & $\begin{array}{l}0.0016^{* * *} \\
(0.0005)\end{array}$ & $\begin{array}{l}0.0016^{* * *} \\
(0.0005)\end{array}$ & $\begin{array}{l}0.0016^{* * *} \\
(0.0005)\end{array}$ \\
\hline Sector orders & Ord & $\begin{array}{l}0.0188 * * * \\
(0.0037)\end{array}$ & $\begin{array}{l}0.0188 * * * \\
(0.0037)\end{array}$ & $\begin{array}{l}0.0186 * * * \\
(0.0037)\end{array}$ & $\begin{array}{l}0.0186 * * * \\
(0.0037)\end{array}$ \\
\hline Yearly dummies & $\gamma$ & Yes & Yes & Yes & Yes \\
\hline Firm’s specific effects & $u$ & Yes & Yes & Yes & Yes \\
\hline $\mathrm{N}^{\circ}$ of obs. & & 1096 & 1096 & 1096 & 1096 \\
\hline $\mathrm{N}^{\circ}$ of firms & & 70 & 70 & 70 & 70 \\
\hline $\mathrm{R}$ - Squared within & & 0.2828 & 0.2828 & 0.2807 & 0.2807 \\
\hline
\end{tabular}


Using the information contained in the survey regarding the proportion of goods produced abroad by each firm when delocalization takes place, a different 'intensity' can be attributed to the delocalization process. The information on delocalized quota refers to year 2003 and it is assumed that this firm-quota has remained the same over the years so the 2003 values give an estimate of the extent of outsourcing over the whole period ${ }^{20}$. This assumption loses any information regarding the gradualness of the process and the estimate results provide a rough indication of the strength of the delocalization process.

Two further outsourcing variables are constructed, which take into account the different productive volumes involved in the event. The quota of goods produced abroad by each company is represented by $Q_{i}$, which varies between zero and one, that multiplied by $D c$ represents the average delocalization effect through the quotas, $Q D c$. The variable $Q T D c$ represents the growth effect of delocalization through the quotas.

These variables replicate the pattern of the variables $D c$ and $T D c$, with the difference that in the presence of active outsourcing the delocalized dummy interacts with the quota of goods actually produced abroad. If, as a first approximation, the relationship between the productive volumes obtained abroad and the dependent variables is linear, the coefficient of the outsourcing variable interacting with the quota indicates how much turnover and EBITDA vary for each percentage point of production delocalized abroad by a delocalizing company. The average effect through the quotas (Tables 2 and 3, col. 4) tells us that for one additional point of the product manufactured abroad, the turnover increases on average by 28 percent, with a negative growth effect of four percent per year, while the EBITDA is not significant.

The decision to delocalize abroad implies moving abroad those phases which were once carried out within the company itself or were delocalized domestically. In the first circumstance the decision to delocalize entails process fragmentation, while in the second circumstance phases already outsourced are moved out of the nation borders. If slicing production and allocating abroad superimpose one another, the estimate blurs the effect attributed to outsourcing with the effect of fragmentation. It is therefore appropriate to disentangle fragmentation from delocalization so as to evaluate the net impact of the offshore alternative. To do so we split the sample in two sub-samples, made by treated and untreated firms:

$>$ treated firms are firms that delocalize abroad and at the same time fragment production,

$>$ non treated firms are firms that delocalize abroad production phases previously outsourced in the domestic market.

\footnotetext{
${ }^{20}$ It resulted very difficult ho have by the interviewed companies a reliable information on the gradualism through time undertaken by the delocalization process.
} 
In order to tackle the problem we define the variable Fra, which is zero for firms which delocalize abroad phases already outsourced domestically and one for firms which transfer abroad phases previously processed within the company, and a variable Nfra, which is zero for companies that outsource production previously processed directly and one for the remaining. The delocalized dummies interact with the fragmentation dummies, giving rise to FraDc, NfraDc and FraTDc, NfraTDc variables. Equation 2 takes into account the delocalization and fragmentation processes

$$
\log \operatorname{Turn}_{t}=\beta_{0}+\beta_{1} F_{r a D \mathcal{G}_{t}}+\beta_{2} \operatorname{FraTD}_{\mathcal{G}_{t}}+\beta_{3} N f r a D \mathcal{G}_{t}+\beta_{4} N f r a T D \mathcal{c}_{t t}+\beta_{5} E_{i t}+\beta_{6} \operatorname{Ord}_{i t}+\gamma_{t}+u_{i}+\varepsilon_{i t}
$$

The splitting of the sample is made on the following assumption: if between the year that precedes and the year that follows the decision to outsource abroad, firm's employment falls considerably (more than ten percent) while the turnover remains more or less the same or rises (we require that it doesn't drop more than five percent) then the firm is defined as treated and the parameter estimate reflects both delocalization abroad and fragmentation. Fourteen firms out of seventy accomplish this assumption, the remaining firms are untreated and their estimate reflects only delocalization, as production was fragmented early in time.

Even in this case it is possible to show the interaction of delocalized variables, the variables referring to the fragmentation processes and the quota of goods produced abroad, in order to take into account different degrees of intensity with which outsourcing occurs. Thus the variables QfraDc, QNfraDc and QfraTDc, QNfraTDc are obtained.

The coefficients of the variables (Table 4, cols. 1 and 3) tell us that delocalization does increase turnover in firms which had already fragmented the production process domestically (plus 14 percent). The average impact for firms that delocalize but hadn't previously outsourced to national subcontractors is larger (plus 22 percent) as expected.

The EBITDA increases by 22 percent for firms which have already fragmented production, while firms that fragment and outsource abroad at the same time show a positive, gradual, profit increase (four percent per year) and a non significant average impact effect. Taking into account the quota (Table 4, cols. 2 and 4), the effect on turnover corresponding to an increase of one percentage point of production shifted abroad by firms which had already outsourced domestically is plus 28 percent, while for firms that both delocalize and split the production process is plus 27 percent. In the case of EBITDA, the net average effect is plus 34 percent for firms that have already fragmented production. The average impact is not significant for firms that delocalize and fragment the processes, but in this case it is accompanied by a strong positive growth effect (plus seven percent per year). 
Tab. 4 - Net/Gross effects of delocalization and fragmentation (Equation 2)

\begin{tabular}{|c|c|c|c|c|c|}
\hline & & \multicolumn{2}{|c|}{ logTurn } & \multicolumn{2}{|c|}{$\log E B I T D A$} \\
\hline & & 1 & 2 & 3 & 4 \\
\hline Average impact and fragmentation & FraDc & $\begin{array}{l}0.2161 * * * \\
(0.0659)\end{array}$ & & $\begin{array}{l}0.0655 \\
(0.1370)\end{array}$ & \\
\hline Growth impact and fragmentation & FraTDc & $\begin{array}{l}-0.0200 * * \\
(0.0096)\end{array}$ & & $\begin{array}{l}0.0434 * * \\
(0.0175)\end{array}$ & \\
\hline Average impact net of fragmentation & NfraDc & $\begin{array}{l}0.1430 * * * \\
(0.0494)\end{array}$ & & $\begin{array}{l}0.2264 * * * \\
(0.0874)\end{array}$ & \\
\hline Growth impact net of fragmentation & NfraTDc & $\begin{array}{l}-0.0274 * * * \\
(0.0103)\end{array}$ & & $\begin{array}{l}-0.0196 \\
(0.0186)\end{array}$ & \\
\hline $\begin{array}{l}\text { Average impact and fragmentation } \\
\text { through quotas }\end{array}$ & QFraDc & & $\begin{array}{l}0.2681^{* * *} \\
(0.1002)\end{array}$ & & $\begin{array}{l}-0.2156 \\
(0.2200)\end{array}$ \\
\hline $\begin{array}{l}\text { Growth impact and fragmentation } \\
\text { through quotas }\end{array}$ & QFraTDc & & $\begin{array}{l}-0.0259^{*} \\
(0.0145)\end{array}$ & & $\begin{array}{l}0.0730 * * \\
(0.0290)\end{array}$ \\
\hline $\begin{array}{l}\text { Average impact net of fragmentation } \\
\text { through quotas }\end{array}$ & QNfraDc & & $\begin{array}{l}0.2839 * * * \\
(0.0947)\end{array}$ & & $\begin{array}{l}0.3360 * * \\
(0.1505)\end{array}$ \\
\hline $\begin{array}{l}\text { Growth impact net of fragmentation } \\
\text { through quotas }\end{array}$ & QNfraTDc & & $\begin{array}{l}-0.0336^{* *} \\
(0.0147)\end{array}$ & & $\begin{array}{l}-0.0332 \\
(0.0310)\end{array}$ \\
\hline Employment & Emp & $\begin{array}{l}0.0020^{* * *} \\
(0.0003)\end{array}$ & $\begin{array}{l}0.0019 * * * \\
(0.0003)\end{array}$ & $\begin{array}{l}0.0017 * * * \\
(0.0005)\end{array}$ & $\begin{array}{l}0.0015 * * * \\
(0.0005)\end{array}$ \\
\hline Sector orders & Ord & $\begin{array}{l}0.0170 * * * \\
(0.0023)\end{array}$ & $\begin{array}{l}0.0177 * * * \\
(0.0024)\end{array}$ & $\begin{array}{l}0.0190 * * * \\
(0.0038)\end{array}$ & $\begin{array}{l}0.0200 * * * \\
(0.0038)\end{array}$ \\
\hline Year dummies & $\gamma$ & Yes & Yes & Yes & Yes \\
\hline Firm’s specific effects & $u$ & Yes & Yes & Yes & Yes \\
\hline $\mathrm{N}^{\circ}$ of obs. & & 1136 & 1136 & 1096 & 1096 \\
\hline $\mathrm{N}^{\circ}$ of firms & & 70 & 70 & 70 & 70 \\
\hline $\mathrm{R}$ - Squared within & & 0.5655 & 0.5635 & 0.2887 & 0.2868 \\
\hline
\end{tabular}

\section{Interpreting the empirical results}

A crucial factor in influencing the decision to move part of the production process abroad is the cost of managing external suppliers. In the short run outsourcing may improve company focus and enables firms to reduce the wage cost by substituting internal labour with cheaper labour owned by the delocalized firms, particularly if located in a low wage country: it is basically a labour cost driven process. The advantage is particularly relevant in case of outsourcing abroad. However outsourcing abroad is accompanied by more complex logistic and increases the administrative overhead.

Many firms that move abroad had previously fragmented the production process domestically (no significant boundary change) and frequently rely on Italian subcontractors that have transferred their plants abroad: additional investments are limited, control and coordination routines are already 
experimented, need adaptation more than creation. The estimates show a sudden positive impact effect on profits due to the wage bill reduction (plus 22 percent) and a turnover increase (plus 14 percent) as going abroad is associated with an increased competitive capacity and larger volumes. The positive impact is once for all and the productivity trajectory doesn't improve or declines ${ }^{21}$ (no positive growth effect). Firms that fragment the process and at the same time move abroad change drastically their market/boundary line: they 'slice’ their production process. Domestic employment is consequently reduced and firms face considerable investments in logistics: new personal relations, process modularity and codification, a set of new organization routines that make the reward of moving abroad much gradual: it is essentially a process of experimentation and learning and the volume increase (plus 22 percent) is accompanied by a gradual profit increase through time (four percent yearly growth).

Our results can be summarised in the following table

Tab. 5 - Delocalization and the boundary of the firm

\begin{tabular}{|l|l|l|l|}
\hline Strategy & $\begin{array}{l}\text { Firm/market } \\
\text { boundary change }\end{array}$ & $\begin{array}{l}\text { Value chain } \\
\text { management (agency } \\
\text { problem) }\end{array}$ & Profitability \\
\hline $\begin{array}{l}\text { Labour cost driven } \\
\text { strategy }\end{array}$ & $\begin{array}{l}\text { No change: outsource } \\
\text { abroad a process } \\
\text { already fragmented }\end{array}$ & $\begin{array}{l}\text { Limited changes } \\
\text { (more complex logistic) }\end{array}$ & $\begin{array}{l}\text { Sudden impact effect } \\
\text { (+22\%), no long run effects }\end{array}$ \\
\hline $\begin{array}{l}\text { Labour cost driven } \\
\text { strategy }\end{array}$ & $\begin{array}{l}\text { Change: outsource } \\
\text { abroad a process } \\
\text { previously vertically } \\
\text { integrated }\end{array}$ & $\begin{array}{l}\text { Considerable investment } \\
\text { in personal relations, } \\
\text { process modularity, } \\
\text { codification,administration }\end{array}$ & $\begin{array}{l}\text { Gradual impact effect (4\% } \\
\text { yearly growth) due to the } \\
\text { requested support for the } \\
\text { new division of labour }\end{array}$ \\
\hline
\end{tabular}

\section{Conclusions}

At the moment information on globalization of Italian firms is extensive but incomplete and bitty. We have analytical data relative to direct overseas investments and their effect on the firms profitability (Barbara Navaretti and Castellani, 2004; Barba Navaretti, Castellani and Disdier, 2006; Castellani, Mariotti and Piscitello, 2006). However, we are aware that globalization is a much vaster phenomenon.

\footnotetext{
${ }^{21}$ In the model presented by Reinstaller and Windrum (2007) outsourcing have a possible long run negative effect on productivity growth because managers might loose competences that are crucial in providing further quality and cost improvements. Very close to our empirical results, they claim that short and long run impacts of outsourcing can have the opposite sign and managers can be, over the long run, locked in low productivity growth trajectories.
} 
This work estimates the effect of organising production in a global value chain framework on the firm turnover and gross earnings. Both subcontracting relations and direct investments abroad are considered. A database has been constructed on the basis of a direct survey, supplemented by information available from the firms' balance sheets and micro employment data. Both the turnover and the gross operative margin positively feels the impact of relocation abroad.

The delocalization strategy, moving abroad significant phases of production and attaining significant unit cost reductions, seems to offer an important contribution in order to increase the level of activity and foster profitability. A higher profitability in turn means to grasp more opportunities of growth and development, and chances of survival for firms facing temporary difficulties.

Delocalization abroad is a measure which has a notable once for all effect both on margins and turnover, however it seems to have no effect on the rate of growth trough time, and therefore we shouldn't expect lasting aggregate effects when all the companies are delocalized. The rationale for this conclusion is that outsourcing, in the majority of cases, occurs with the transfer abroad of phases and processes previously carried out in Italy, urged on by increased price competition at the international level, while the machinery and the production techniques remain substantially unchanged. A sequence of governance innovations (product modularisation, export of knowledge, etc.) is required that is liable to further increase productivity and encourage the use of new technologies in order to continue the positive run.

Working in a more and more complex international context encourages the final producers to improve managerial and organisational efficiency and increases domestic demand for skilled high value added services ${ }^{22}$. Nonetheless the choice to delocalize abroad has an immediate strong negative impact on employment in small artisan laboratories and on the connected skills, particularly in a region where the number of people employed in manufacturing is high, as in the Veneto in clothing and footwear sectors, and domestic outsourcing has been common practice (Tattara, 2001). The negative consequence of the drastic reduction of domestic outsourcing in the region and the crisis of some big brands which have not been able to manage the value chain at an international level, is evident.

In an area which has always been characterized by the presence of small firms clustered in industrial districts, the destiny of the firm has often been considered in symbiosis with that of the workers: a mutual solidarity connects entrepreneurs, territory and society towards the attainment of a mutual progress. In the recent decade the firms of the Veneto clothing and footwear districts are leading their way along a different trend. Profit realization is now farther and farther away from

\footnotetext{
${ }^{22}$ Gereffi (1999) stresses that being part of a value chain at an international level means acquiring knowledge and therefore having a significant production upgrading.
} 
places where companies that lead the productive chains are located. Therefore a profit increase by the final producers no longer directly reflects positive corresponding variations in local employment and in local revenues and this inevitably corrodes some of the constituent characters of the industrial district.

\section{References}

Adam, G. (1971), 'New trends in international business: worldwide sourcing and dedomiciling', Acta Oeconomica, 7 (3-4), 349-367.

Baden, S. (2002), 'Trade Policy, Retail Markets and Value Chain Restructuring in the EU Clothing Sector’, PRUS working paper, n. 9.

Barba Navaretti, G. and D. Castellani (2004), 'Investments abroad and performance at home: evidence from Italian multinationals’, CEPR discussion paper, n. 4284.

Barba Navaretti, G., D. Castellani and A. C. Disdier (2006), 'How does investing in cheap countries affect performance at home? France and Italy’, CEPR discussion paper, n. 5765.

Bénassy-Quéré, A., L. Fontagné and A. Lahréche-Révil (2005), 'How Does FDI React to Corporate Taxation?’, International Tax and Public Finance, 12 (5), 583-603.

Ginzburg, A. and D. Bigarelli (2004), I confini delle imprese, Reggio Emilia, Italy: Reggio Emilia Chamber of Commerce.

Brusco, S. (1975), 'Organizzazione del lavoro e decentramento produttivo nel settore metalmeccanico', reprinted in S. Brusco (1989), Piccole imprese e distretti industriali, Torino, Italy: Rosemberg and Sellier, pp. 59-153.

Bugamelli, M., P. Cipollone and L. Infante (2000), 'L'internazionalizzazione produttiva delle imprese italiane negli anni novanta’, Rivista italiana degli economisti, 5 (3), 349-386.

Capitalia (2003), 'Osservatorio sulle piccole e medie imprese indagine sulle imprese manifatturiere’, Ottavo rapporto sull'industria italiana e sulla politica industriale.

Capitalia (2005), 'Indagine sulle imprese italiane, tavole statistiche allegate al rapporto sul sistema produttivo e la politica industriale’.

Caprio, L. (2002), 'Diffusione e alcune caratteristiche dei gruppi di medie imprese industriali nel Nord Est', Mediobanca and Unioncamere working paper.

Castellani, D., I. Mariotti and L. Piscitello (2006), 'Attività estere delle imprese multinazionali italiane e "skill upgrading”, in Mariotti S. and L. Piscitello (eds) (2006), Multinazionali, innovazione e strategie per la competitività, Bologna, Italy: Il Mulino, pp. 165-183.

CEPS (2005), 'The Textiles and Clothing Industries in an Enlarged Community and the Outlook in the Candidate States', Final report, part 1.

Coro’, G. and M. Volpe (2003), ‘Frammentazione produttiva e apertura internazionale nei sistemi di piccola e media impresa', Economia e società regionale, 81 (1), 67-107.

Crestanello, P. (1999), L'industria veneta dell'abbigliamento: internazionalizzazione produttiva e imprese di subfornitura, Milano, Italy: Franco Angeli.

Crestanello, P. and P. E. Dalla Libera (2003), 'La delocalizzazione produttiva all'estero nell'industria della moda: il caso di Vicenza', Economia e società regionale, 82 (2), 5-45. 
Crestanello, P. and G. Tattara (2007), ‘A Global Network and its Local Ties. Competition and Restructuring of the Benetton Group', paper presented at the SASE Meeting Copenhagen, 29 June 2007.

European Community Commission (EC) (1996), 'Communication from the commission. The competitiveness of subcontracting in the textile and clothing industry in the European Union', Com 96.201.

Feenstra, R. (1998), 'Integration of Trade and Disintegration of Production in the Global Economy', Journal of Economic Perspectives, 12 (4), 31-50.

Finger, J. M. (1976), 'Trade and domestic effects of offshore assembly provision in the U.S. tariff', The American Economic Review, 66 (4), 598-611.

Finger, J. M. (1977), 'Offshore Assembly Provision in the West German and Netherlands Tariffs: Trade and Domestic Effects’, Weltwirtschaftliches Archiv, 113 (2), 237-249.

Gereffi, G. (1999), 'International Trade and Industrial Upgrading in the Apparel Commodity Chain', Journal of International Economics, 48 (1), 37-70.

Gereffi, G. (2002), 'The international competitiveness of Asian economies in the apparel commodity chain', ERD working paper, n. 5.

Gereffi, G., J. Humphrey and T. Sturgeon (2005), 'The Governance of Global Value Chain', Review of International Political Economy, 12 (1), 78-104.

Gianelle, C. (2005), 'Il Veneto che produce all'estero: una ricerca empirica sulla delocalizzazione delle imprese di abbigliamento’, Economia e società regionale, 90 (2), 37-62.

Gomirato, E. (2004), 'La delocalizzazione dell'abbigliamento in Romania: il caso Stefanel', Economia e società regionale, 86 (2), 63-91.

Gordon, M. J. (2004), 'How Third World Contracting is Transformed into First World Productivity’, Challenge, 47 (1), 78-85.

Graziani, G. (1998), 'Globalization of production in textile and clothing industries: The case of Italian foreign direct investment and outward processing in eastern Europe', in Zysman J. and A. Schwartz (eds), Enlarging Europe: The Industrial Foundations of a New Political Reality, International and Area Studies, Research Series, n. 99, University of California, pp. 238-254.

Graziani, G. (2001), 'International Subcontracting in the Textile and Clothing Industry', in Arndt S.W. and H. Kierzkowsky (eds), Fragmentation. New Production Patterns in the World Economy, Oxford, UK: Oxford University Press, pp. 209-230.

Heckman, J.J. and R. Robb Jr. (1985), 'Alternative Methods for Evaluating the Impact of Interventions', in Heckman J.J. and B. Singer (eds), Longitudinal Analysis of Labour Market Data, Cambridge, UK: Cambridge University Press, pp. 156-246.

Heckman, J.J. and J.A. Smith (1999), 'The Pre-Programme Earnings Dip and the Determinants of Participation in a Social Programme. Implications for Simple Programme Evaluation Strategies', The Economic Journal, 109 (457), 313-348.

Hsiao, C. (2003), Analysis of Panel Data, ,Cambridge, UK: Cambridge University Press.

Kaminsky, B. and F. NG (2001), 'Trade and Production Fragmentation: Central European Economies. EU Networks of Production and Marketing', World Bank discussion paper.

Mediobanca and Unioncamere (2003), Le medie imprese industriali del Nord Est (1996-2000), Milano-Roma, Italy. 
Melitz, M. (2003), 'The impact of trade on intraindustry reallocations and aggregate industry productivity’, Econometrica, 71 (6), 1695-1725.

Nardin, G. (1987), La Benetton. Strategia e struttura di un'impresa di successo, Roma, Italy: Edizioni lavoro.

Owen, G. (2001), 'Globalisation in textiles: corporate strategy and competitive advantage', The third annual Pasold lecture, 11 December 2001.

Reinstaller, A. and P. Windrum (2007), 'Short-term gain, long-term pain?: implications of outsourcing for organisational innovation and productivity', in Morroni M. (ed.), Corporate Governance, Organization and the Firm: Co-operation and Outsourcing in a Globalized Market, Cheltenham, UK: Edward Elgar, in press.

Schiattarella, R. (1999), 'La delocalizzazione internazionale: problemi di definizione e di misurazione. Un'analisi per il settore del "Made in Italy", Economia e Politica Industriale, 103, 207-239.

Stevanato, D. (2004), 'Fisco e delocalizzazione', Economia e società regionale, 87 (3), 84-104.

Tattara, G. (ed.) (2001), Il piccolo che nasce dal grande, Milano, Italy: Franco Angeli.

Tattara, G. (2007), 'Emerging Hubs in Central-Eastern Europe, Trade Blocs and Financial Cooperation', in Capture and Exclude: Developing Economies and the Poor in Global Finance, New Delhi, India: Tulika Books, in press. 


\section{Appendix}

A1. Descriptive statistics of the companies included in the sample, year 2001

\begin{tabular}{ll}
\hline Firms in clothing sector & 40 (10 knitwear) \\
Firms in footwear sector & 30 \\
Average $n^{\circ}$ of employees & 110 \\
Average turnover (thousands of Euros) & 36.300 \\
Average EBITDA (thousands of Euros) & 2.600 \\
Firms with FDI & 34 \\
Average $n^{\circ}$ of observations per firm in the panel & 16.3 \\
Average $n^{\circ}$ of observations before relocation & 8.8 \\
Average $n^{\circ}$ of observations after relocation & 7.5 \\
& \\
First 10 countries of delocalization in order of importance: & \\
$\quad$ Romania & \\
China & \\
Tunisia & \\
Hungary & \\
Bulgaria & \\
Croatia & \\
Turkey & \\
Slovakia & \\
India & \\
Indonesia & \\
\end{tabular}

A2. Limited and joint stock companies.

\begin{tabular}{|c|c|c|c|c|c|c|c|c|c|c|}
\hline \multirow{2}{*}{$\begin{array}{l}\text { Employment } \\
\text { class }\end{array}$} & \multicolumn{4}{|c|}{ present sample (2003) } & \multicolumn{4}{|c|}{ Veneto (2001) } & \multicolumn{2}{|c|}{ Sample \% over Veneto } \\
\hline & \multicolumn{2}{|c|}{ Companies } & \multicolumn{2}{|c|}{ Employees } & \multicolumn{2}{|c|}{ Companies } & \multicolumn{2}{|c|}{ Employees } & \multirow{2}{*}{$\begin{array}{c}\text { Companies } \\
0.7\end{array}$} & \multirow{2}{*}{$\begin{array}{c}\text { Employees } \\
1.6\end{array}$} \\
\hline $1-19$ & 6 & $(8 \%)$ & 80 & $(1 \%)$ & 858 & $(60 \%)$ & 80 & (1\%) & & \\
\hline $20-49$ & 16 & (23\%) & 577 & $(8 \%)$ & 323 & (25\%) & 577 & $(8 \%)$ & 4.5 & 5.6 \\
\hline $50-99$ & 21 & (30\%) & 1472 & (19\%) & 110 & $(9 \%)$ & 1472 & (19\%) & 16.0 & 16.6 \\
\hline $100-249$ & 21 & (30\%) & 3108 & $(40 \%)$ & 45 & $(4 \%)$ & 3108 & $(40 \%)$ & 36.8 & 41.3 \\
\hline 250 and more & 6 & $(9 \%)$ & 2494 & $(32 \%)$ & 25 & $(2 \%)$ & 2494 & $(32 \%)$ & 24.0 & 24.9 \\
\hline Total & 70 & $(100 \%)$ & 7731 & $(100 \%)$ & 1427 & $(100 \%)$ & 7731 & $(100 \%)$ & 4.9 & 18.5 \\
\hline
\end{tabular}

Source: survey; Census of production, Istat, 2001: < http://www.istat.it/censimenti/> 